\title{
Paradoxical relationship between RAVE (relative activity versus endocytosis) values of several opioid receptor agonists and their liability to cause depen- dence
}

\author{
Yu-hua WANG ${ }^{1,2,3}$, Jian-feng SUN ${ }^{3}$, Yi-min $\mathrm{TAO}^{3}$, Xue-jun $\mathrm{XU}^{3}$, Zhi-qiang $\mathrm{CHI}^{3}$, Jing-gen $\mathrm{LIU}^{3, *}$ \\ ${ }^{1}$ School of Pharmacy, China Pharmaceutical University, Nanjing 210009, China; ${ }^{2}$ School of Pharmacy, Nanjing University of Chinese \\ Medicine, Nanjing 210046, China; ${ }^{3}$ State Key Laboratory of Drug Research, Shanghai Institute of Materia Medica, Shanghai Institutes \\ for Biological Sciences, Chinese Academy of Sciences, Shanghai 201203, China
}

\begin{abstract}
Aim: To examine the relationship between the RAVE (relative activity versus endocytosis) values of opiate agonists and their dependence liability by studying several potent analgesics with special profiles in the development of physical and psychological dependence.

Methods: The effects of (-)-cis-(3R,4S,2'R) ohmefentanyl (F9202), (+)-cis-(3R,4S,2'S) ohmefentanyl (F9204), dihydroetorphine (DHE) and morphine on $\left[{ }^{35} \mathrm{~S}\right] \mathrm{GTPYS}$ binding, forskolin-stimulated cAMP accumulation, and receptor internalization were studied in $\mathrm{CHO}$ cells stably expressing HA-tagged $\mu$-opioid receptors (CHO-HA-MOR). cAMP overshoot in response to the withdrawal of these compound treatments was also tested.

Results: All four agonists exhibited the same rank order of activity in stimulation of $\left[{ }^{35} \mathrm{~S}\right] \mathrm{GTP}$ S binding, inhibition of adenylyl cyclase (AC) and induction of receptor internalization: DHE>F9204>F9202>morphine. Based on these findings and the previous in vivo analgesic data obtained from our and other laboratories, the RAVE values of the four agonists were calculated. The rank order of RAVE values was morphine>F9202>F9204>DHE. For the induction of cAMP overshoot, the rank order was F9202 $\geq$ morphine>F9204 $\geq$ DHE. Conclusion: Taken in combination with previous findings of these compounds' liability to develop dependence, the present study suggests that the agonist with the highest RAVE value seems to have a relatively greater liability to develop psychological dependence relative to the agonist with the lowest RAVE value. However, the RAVE values of these agonists are not correlated with their probability of developing physical dependence or inducing cAMP overshoot, a cellular hallmark of dependence.
\end{abstract}

Keywords: RAVE; $\mu$-opioid receptor; cyclic AMP; endocytosis; physical dependence; psychological dependence

Acta Pharmacologica Sinica (2010) 31: 393-398; doi: 10.1038/aps.2010.19; published online 15 Mar 2010

\section{Introduction}

Although opioids are highly effective for the relief of pain, their therapeutic utility is limited by the tendency to cause undesirable addiction following repeated or prolonged administration. The cellular and molecular mechanisms underlying opioid dependence remain unclear. Many reports demonstrate that the $\mu$-opioid receptors (MORs) play a central role in morphine-induced analgesia, dependence and addiction ${ }^{[1-3]}$. The function of MORs is regulated by multiple mechanisms such as receptor phosphorylation, desensitization, and inter-

\footnotetext{
* To whom correspondence should be addressed.

E-mail jgliu@mail.shcnc.ac.cn

Received 2009-12-06 Accepted 2010-01-22
}

nalization. Of these regulatory mechanisms, receptor internalization appears to play an important role in the modulation of opioid receptor signal transduction. The internalized receptor could either recycle from the endosomes to the plasma membrane to cause resensitization or be degraded in the lysosomes to induce receptor down-regulation and long-term desensitiza$\operatorname{tion}^{[4-6]}$. Moreover, several studies have suggested that receptor endocytosis might crucially modulate the development of opioid dependence ${ }^{[7-9]}$.

Morphine is well known as a unique analgesic among opiates for its ability to activate the MOR without promoting significant receptor endocytosis ${ }^{[10-12]}$. As a consequence, the signal transduction is prolonged through the receptor, which leads to multiple cellular adaptations. These adaptive cellular 
changes may contribute to the pronounced in vivo dependence that occurs with chronic morphine treatment ${ }^{[12-14]}$. On the contrary, etorphine and endogenous peptide ligands drive a robust receptor endocytosis but display a relatively lower liability to develop dependence ${ }^{[14-16]}$. Based on these findings, Whistler and colleagues have proposed that the value of relative activity versus endocytosis (RAVE) could be used to predict the liability of opioid agonists to develop dependence ${ }^{[14,17]}$. However, the relationship between the RAVE value and the opioid dependence has not been fully confirmed.

In the present study, we explore this relationship by establishing the RAVE values of several potent analgesics with special characteristics and correlating their role in the development of physical and psychological dependence. This was accomplished by studying the effects of F9202, F9204, DHE, and morphine on the stimulation of $\left[{ }^{35} \mathrm{~S}\right] \mathrm{GTP} \gamma \mathrm{S}$ binding, inhibition of forskolin-stimulated cAMP accumulation and induction of receptor internalization in CHO-HA-MOR cells. In addition, we also determined the cAMP overshoot in response to the withdrawal of chronic drug treatment in CHO-HAMOR cells.

\section{Materials and methods Cell culture}

CHO cells were transfected with rat MORs using Lipofectamine (Invitrogen) according to the manufacturer's protocol. CHO cells stably expressing HA-tagged rat MORs (CHOHA-MOR) were maintained in F12 medium (Gibco) with 10\% fetal calf serum and $0.25 \mathrm{~g} / \mathrm{L}$ G418 (Roche). Cells were incubated in a humidified atmosphere consisting of $5 \% \mathrm{CO}_{2}$ and $95 \%$ air at $37^{\circ} \mathrm{C}$. For receptor binding and $\left[{ }^{35} \mathrm{~S}\right] \mathrm{GTP} Y \mathrm{~S}$ binding experiments, cells were seeded into $175-\mathrm{cm}^{2}$ flasks. When cell growth reached $70 \%$ confluence, cells were washed with phosphate-buffered saline (PBS) and the membrane was prepared.

\section{Cell membrane preparation}

CHO-HA-MOR cells were detached by incubation with phosphate-buffered saline containing $1 \mathrm{mmol} / \mathrm{L}$ EDTA and centrifuged at $1000 \times g$ for $10 \mathrm{~min}\left(4^{\circ} \mathrm{C}\right)$. The cell pellet was suspended in ice-cold homogenization buffer composed of $50 \mathrm{mmol} / \mathrm{L}$ HEPES, pH 7.4, $1 \mathrm{mmol} / \mathrm{L} \mathrm{MgCl}_{2}$, and $1 \mathrm{mmol} / \mathrm{L}$ EGTA. Cells were homogenized by 10 strokes with a glass Dounce homogenizer. After centrifugation at $40000 \times g$ for 10 $\min \left(4^{\circ} \mathrm{C}\right)$, pellets were resuspended in homogenization buffer, homogenized, and centrifuged again as described. This procedure was repeated twice more. The final pellets were resuspended in a $50 \mathrm{mmol} / \mathrm{L}$ Tris- $\mathrm{HCl}$ buffer, $\mathrm{pH}$ 7.4. The protein concentration was determined and aliquots were stored at $-80^{\circ} \mathrm{C}$.

\section{GTPYS binding assay}

$\left.{ }^{35} \mathrm{~S}\right] \mathrm{GTP} \mathrm{S}$ binding was performed as described previously ${ }^{[18]}$. Briefly, membranes $(15 \mu \mathrm{g} /$ tube) were incubated with $0.1 \mathrm{nmol} / \mathrm{L}\left[{ }^{35} \mathrm{~S}\right] \mathrm{GTP} \gamma \mathrm{S}$ in a binding buffer composed of $50 \mathrm{mmol} / \mathrm{L}$ Tris-HCl, pH 7.5, $1 \mathrm{mmol} / \mathrm{L}$ EDTA, $5 \mathrm{mmol} / \mathrm{L}$ $\mathrm{MgCl}_{2}, 100 \mathrm{mmol} / \mathrm{L} \mathrm{NaCl}$, and $40 \mu \mathrm{mol} / \mathrm{L}$ GDP at $30{ }^{\circ} \mathrm{C}$ for
$1 \mathrm{~h}$ in the presence of increasing concentrations of F9202, F9204, morphine, and DHE. Nonspecific binding was determined in the presence of nonradioactive GTPYS $(10 \mu \mathrm{mol} / \mathrm{L})$. Reactions were terminated by rapid filtration through GF/B filters (Whatman) and bound radioactivity was determined by liquid scintillation counting (Beckman LS6500).

\section{cAMP accumulation assay}

CHO-HA-MOR cells were assayed for intracellular cAMP accumulation as described previously ${ }^{[18]}$, with some modifications. In brief, the cells were either pretreated (for the cAMP overshoot assay) or not (for inhibition of cAMP accumulation) with opioid drugs for $24 \mathrm{~h}$ at $37^{\circ} \mathrm{C}$. After the treatment, the cells were harvested with $1 \mathrm{mmol} / \mathrm{L}$ EDTA in PBS and then resuspended in Stimulation Buffer [Hanks' Balanced Salt Solution (HBSS) containing $0.5 \mathrm{mmol} / \mathrm{L} \mathrm{IBMX}, 5 \mathrm{mmol} / \mathrm{L}$ HEPES, $0.1 \%$ BSA, PH 7.4] to obtain 12000 cells per $10 \mu \mathrm{L}$, followed by adding the Alexa Fluor ${ }^{\circledR}$ 647-labeled antibodies to the cell suspension (1:100). Subsequently, the cells were incubated with $10 \mu \mathrm{mol} / \mathrm{L}$ forskolin, $10 \mu \mathrm{mol} / \mathrm{L}$ naloxone (for cAMP overshoot assay) and opioid drugs for $30 \mathrm{~min}$ at room temperature. The assay procedures followed the protocol provided in a LANCE $^{\circledR}$ cAMP Kit (PerkinElmer, Inc, Waltham, MA). Luminescence was measured with a NOVO star (BMG Labtechnologies, Germany) plate reader.

\section{Flow cytometric analysis}

For the detection of surface receptor internalization, surface receptors were quantified using a fluorescence flow cytometry assay as previously described ${ }^{[19]}$, with slight modification. In brief, CHO-HA-MOR cells were treated with F9202, F9204, morphine, or DHE for $1 \mathrm{~h}$ at the indicated concentrations after having been starved by serum-free F12 medium for $4 \mathrm{~h}$ at $37^{\circ} \mathrm{C}$. Cells were then chilled to $0{ }^{\circ} \mathrm{C}$ to arrest further trafficking and stained on ice with $3.75 \mu \mathrm{g} / \mathrm{mL}$ FITC-conjugated antiHA antibody (Sigma) in PBS for $4 \mathrm{~h}$. All cells were harvested from the wells with $1 \mathrm{mmol} / \mathrm{L}$ EDTA in PBS on ice and analyzed on a FACScan flow cytometer with CellQuest 3.0.1 for acquisition and analysis (Becton Dickinson, Mountain View, CA). Live cells were gated by light scatter and 10000 cells were acquired for each sample. The mean fluorescence of stained cells minus the mean fluorescence of unstained cells was used to calculate the percentage of surface receptor staining.

\section{Materials}

Guanosine 5-O-(3-[ $\left.{ }^{35} \mathrm{~S}\right]$ thio)triphosphate ([ $\left.\left.{ }^{35} \mathrm{~S}\right] \mathrm{GTP} \gamma \mathrm{S}\right)(46.25$ $\mathrm{TBq} / \mathrm{mmol}$ ) was purchased from Amersham Biosciences (Piscataway, NJ). GTPYS, GDP, FITC-conjugated anti-HA antibody, 3-Isobutyl-1-methylxanthine (IBMX), forskolin and naloxone were supplied by Sigma-Aldrich (St Louis, MO). Morphine was purchased from Qinghai Pharmaceutical Factory (Xining, China). Dihydroetorphine (DHE) was a gift from Prof Jin LI (Beijing Institute of Pharmacology and Toxicology). F9202 and F9204 were synthesized by the Shanghai Institute of Materia Medica, Chinese Academy of Sciences (Shanghai, China). The LANCE $^{\circledast}$ cAMP Kit was purchased from 
PerkinElmer, Inc (Waltham, MA). All other compounds were obtained from commercial sources.

\section{Statistical analysis}

Curve-fitting analyses were performed using GraphPad Prism 5.0 software (GraphPad software, San Diego, CA, USA). Data represent the mean $\pm S E M$ of at least three separate experiments. Statistical significance was determined by one-way ANOVA followed by post hoc comparison using Tukey's test. When only two groups were compared, statistical significance was determined by an unpaired Student's $t$-test.

\section{Results}

The effects of F9202, F9204, DHE and morphine on stimulating $\left[{ }^{35} \mathrm{~S}\right] \mathrm{GTPYS}$ binding to the membranes of CHO-HA-MOR cells

The $\left[{ }^{35} \mathrm{~S}\right] \mathrm{GTP} \gamma \mathrm{S}$ binding assay is one of the most widely used methods to evaluate the efficacy of agonists to activate heterotrimeric $G$ protein at the initial stage of signal transduction. The binding of $\left[{ }^{35} \mathrm{~S}\right] \mathrm{GTP} \gamma \mathrm{S}$ to membranes of CHO-HA-MOR cells was stimulated by F9202, F9204, DHE, and morphine in a concentration-dependent manner (Figure 1). F9202, F9204, and DHE all displayed extraordinarily high potency to activate $\mathrm{MOR}$ with $\mathrm{EC}_{50}$ values of $4.90 \pm 1.10,1.35 \pm 0.12$, and $0.84 \pm 0.18 \mathrm{pmol} / \mathrm{L}$, respectively (Table 1 ). Consistent with previous studies showing that the $\mathrm{EC}_{50}$ value of morphine was in the nanomolar range ${ }^{[20,21]}$, morphine stimulated binding of $\left[{ }^{35} \mathrm{~S}\right] \mathrm{GTP} \gamma \mathrm{S}$ to membranes of CHO-HA-MOR cells with an $\mathrm{EC}_{50}$ value of $15.69 \pm 4.76 \mathrm{nmol} / \mathrm{L}$ which was approximately 3000-20 000 times greater than that of F9202, F9204, and DHE. Based on the $\mathrm{EC}_{50}$ values, the rank order of these agonists' ability to activate $G$ protein was DHE>F9204>F9202>morphine.

The effects of F9202, F9204, DHE, and morphine on forskolinstimulated CAMP accumulation in CHO-HA-MOR cells

Activation of opioid receptors inhibits adenylyl cyclase activity, leading to a reduction of the intracellular cAMP accumulation $^{[22]}$. To compare the activities of the four compounds, the cAMP assay was performed to determine their ability to inhibit adenylyl cyclase in CHO-HA-MOR cells. All four of the compounds inhibited a forskolin $(10 \mu \mathrm{mol} / \mathrm{L})$-stimulated increase in intracellular cAMP concentrations in a dosedependent manner (Figure 2). In agreement with previous

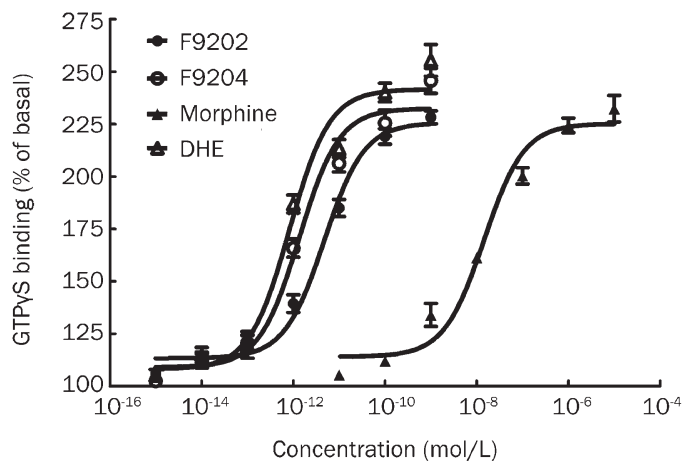

Figure 1. The effects of F9202, F9204, DHE, and morphine on the stimulation of $\left[{ }^{35} \mathrm{~S}\right] \mathrm{GTPYS}$ binding to membranes of $\mathrm{CHO}-\mathrm{HA}-\mathrm{MOR}$ cells. $\left[{ }^{35} \mathrm{~S}\right] \mathrm{GTPYS}$ binding was performed as described under Materials and methods. Data obtained at each drug concentration were normalized to the percentage of the basal $\left[{ }^{35} \mathrm{~S}\right] \mathrm{GTP}$ S binding. Each data point represents the mean \pm SEM of at least three independent experiments conducted in triplicate. $\mathrm{EC}_{50}$ values are shown in Table 1.

studies $^{[10,23]}$, morphine inhibited forskolin-stimulated intracellular cAMP with an $\mathrm{IC}_{50}$ value in the nanomolar range $(14.25 \pm 2.72 \mathrm{nmol} / \mathrm{L})$. F9202, F9204, and DHE exhibited a more potent ability to inhibit intracellular cAMP accumulation than morphine with $\mathrm{IC}_{50}$ values of $0.63 \pm 0.09,0.11 \pm 0.03$, and $0.08 \pm 0.01 \mathrm{nmol} / \mathrm{L}$, respectively (Table 1 ). The $\mathrm{IC}_{50}$ values of F9202, F9204, and DHE were 23.21, 129.55, and 178.13 fold less than that of morphine, respectively. However, these compounds showed a similar maximal level of inhibition (Figure 2). At a concentration of $1 \mu \mathrm{mol} / \mathrm{L}$, they inhibited cAMP production to $23.32 \% \pm 0.10 \%, 23.09 \% \pm 3.23 \%, 24.24 \% \pm 4.13 \%$, and $17.22 \% \pm 1.57 \%$ of the control, respectively. Based on the $\mathrm{IC}_{50}$ values, the rank order of these agonists' ability to inhibit adenylyl cyclase activity was DHE>F9204>F9202>morphine.

\section{The effects of F9202, F9204, DHE, and morphine on MORs} endocytosis in CHO-HA-MOR cells

Next, a flow cytometry assay was performed to quantify the endocytosis of HA-tagged MORs in intact $\mathrm{CHO}$ cells using immunostaining with a FITC-labeled anti-HA antibody. F9202, F9204, and DHE were observed to stimulate the robust endocytosis of MORs (Figure 3, Table 1) with

Table 1. Effects of F9202, F9204, DHE, and morphine on $\left[{ }^{35} \mathrm{~S}\right] \mathrm{GTPYS}$ binding, AC inhibition, receptor endocytosis in CHO-HA-MOR cells and analgesic activity in mice. ${ }^{b} P<0.05,{ }^{c} P<0.01$ vs DHE-treated group. (One-way ANOVA, Tukey post tests).

\begin{tabular}{|c|c|c|c|c|c|c|c|c|c|c|}
\hline \multirow[t]{2}{*}{ Drug } & \multicolumn{2}{|c|}{$\left[{ }^{35} \mathrm{~S}\right] \mathrm{GTPYS}$ binding } & \multicolumn{2}{|c|}{ AC inhibition } & \multirow{2}{*}{$\begin{array}{l}\text { Analgesic } \\
\text { potency }{ }^{[35,36]} \\
\text { Relative } \\
\text { activity (C) }\end{array}$} & \multicolumn{2}{|c|}{ Endocytosis } & \multirow{2}{*}{$\begin{array}{l}\text { A/D } \\
\text { (RAVE) }\end{array}$} & \multirow{2}{*}{$\begin{array}{l}\text { B/D } \\
\text { (RAVE) }\end{array}$} & \multirow{2}{*}{$\begin{array}{l}\text { C/D } \\
\text { (RAVE) }\end{array}$} \\
\hline & $\begin{array}{l}\text { Activity }\left(\mathrm{EC}_{50}\right) \\
(\mathrm{pmol} / \mathrm{L})\end{array}$ & $\begin{array}{l}\text { Relative } \\
\text { activity (A) }\end{array}$ & $\begin{array}{c}\text { Activity }\left(\mathrm{EC}_{50}\right) \\
(\mathrm{nmol} / \mathrm{L})\end{array}$ & $\begin{array}{c}\text { Relative } \\
\text { activity (B) }\end{array}$ & & $\begin{array}{c}\mathrm{EC}_{50} \\
(\mathrm{nmol} / \mathrm{L})\end{array}$ & $\begin{array}{c}\text { Relative } \\
\text { endocytosis (D) }\end{array}$ & & & \\
\hline F9202 & $4.90 \pm 1.10^{c}$ & 0.17 & $0.63 \pm 0.09^{\circ}$ & 0.13 & 0.24 & $4.02 \pm 0.84^{c}$ & 0.055 & 3.09 & 2.36 & 4.36 \\
\hline F9204 & $1.35 \pm 0.12^{b}$ & 0.62 & $0.11 \pm 0.03$ & 0.74 & 0.98 & $0.58 \pm 0.10^{c}$ & 0.38 & 1.63 & 1.95 & 2.57 \\
\hline
\end{tabular}




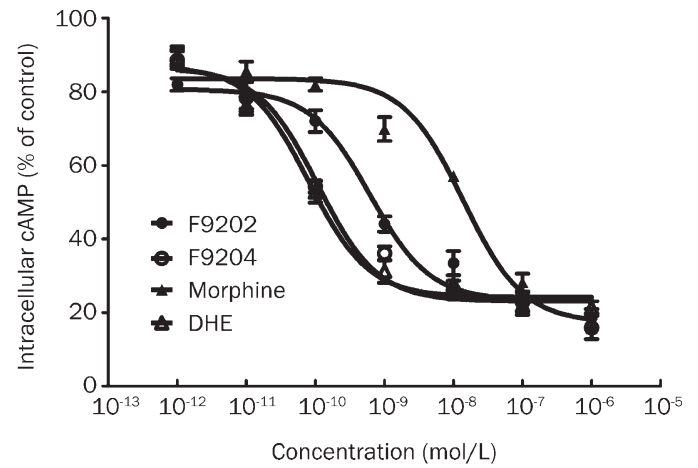

Figure 2. The effects of F9202, F9204, DHE, and morphine on forskolinstimulated cAMP accumulation in CHO-HA-MOR cells. CHO-HA-MOR cells were assayed for the inhibition of CAMP accumulation using F9202, F9204, morphine, and DHE as described under Materials and methods. The forskolin-stimulated intracellular cAMP level in the absence of opioid agonists was defined as $100 \%$, and the percentage of cAMP inhibition was calculated from the forskolin control value. Each data point represents the mean \pm SEM of at least three independent experiments conducted in triplicate. $\mathrm{IC}_{50}$ values are shown in Table 1.

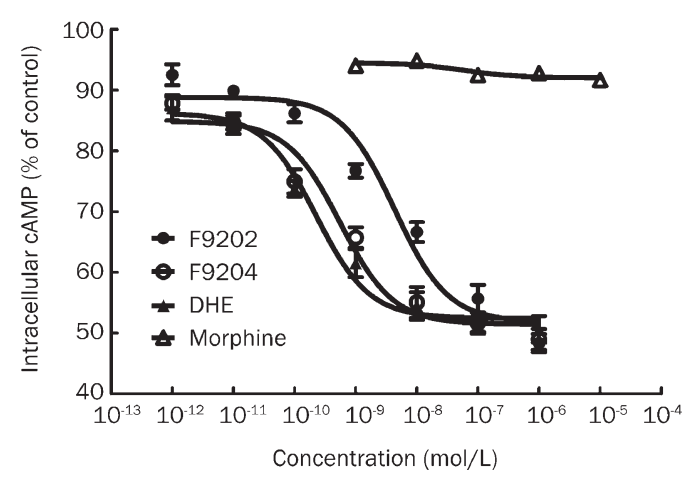

Figure 3. The effects of F9202, F9204, DHE, and morphine on $\mu$-opioid receptors endocytosis. Flow cytometric analysis was employed as described under Materials and methods. The cells were treated with various concentrations of drugs for $1 \mathrm{~h}$ at $37^{\circ} \mathrm{C}$. Values are the mean \pm SEM of triplicate determinations in a representative experiment. $\mathrm{EC}_{50}$ values are shown in Table 1.

$\mathrm{EC}_{50}$ values of $4.02 \pm 0.84,0.58 \pm 0.10$, and $0.22 \pm 0.07$ and maximal endocytosic values of $52.49 \% \pm 1.98 \%, 52.11 \% \pm 3.44 \%$, and $51.38 \% \pm 2.88 \%$ at a concentration of $1 \mu \mathrm{mol} / \mathrm{L}$, respectively. The $\mathrm{EC}_{50}$ values of DHE were 2.62 and 18.19 fold less than that of F9204 and F9202, respectively. Consistent with previous studies, morphine failed to cause any detectable endocytosis of MORs under the same conditions even at a concentration of $10 \mu \mathrm{mol} / \mathrm{L}^{[10,24]}$. The rank order of these compounds' ability to induce receptor endocytosis was DHE $>$ F9204>F9202>morphine.

The effects of chronic F9202, F9204, DHE and morphine on cAMP overshoot in CHO-HA-MOR cells

cAMP overshoot is commonly accepted as a cellular hall- mark of opiate withdrawal and dependence ${ }^{[6,25-27]}$. To compare the dependence liability of these four agonists, the cAMP overshoot in the presence of naloxone $(10 \mu \mathrm{mol} / \mathrm{L})$ was determined in intact CHO-HA-MOR cells. Forskolinstimulated cAMP accumulation in the absence of opioid agonist was defined as $100 \%$, and the percentage of the intracellular cAMP level was calculated from the forskolin control value. Chronic treatment of cells with morphine (1 $\mu \mathrm{mol} / \mathrm{L})$ and F9202 $(1 \mu \mathrm{mol} / \mathrm{L})$ for $24 \mathrm{~h}$ greatly augmented forskolin $(10 \mu \mathrm{mol} / \mathrm{L})$-stimulated intracellular cAMP formation to $308.67 \% \pm 16.56 \%$ and $325.67 \% \pm 27.65 \%$ of the control levels, respectively (Figure 4). However, when the cells were pretreated with DHE $(1 \mu \mathrm{mol} / \mathrm{L})$ or F9204 $(1 \mu \mathrm{mol} / \mathrm{L})$ for $24 \mathrm{~h}$, the magnitude of cAMP overshoot was significantly $(P<0.001)$ lower than that observed after morphine or F9202 pretreatment. The intracellular cAMP levels of DHE and F9204 were $159.00 \% \pm 18.08 \%$ and $192.00 \% \pm 19.00 \%$ of the control levels, respectively. Based on these results, the rank order of the four drugs' potency to induce cellular dependence was F9202 $\geq$ morphine $>$ F9204 $\geq$ DHE.

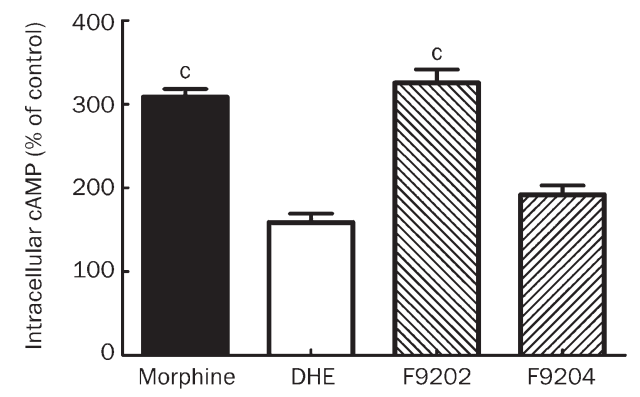

Figure 4. The effects of chronic F9202, F9204, DHE, and morphine on cAMP overshoot in CHO-HA-MOR cells. CHO-HA-MOR cells were pretreated with morphine $(1 \mu \mathrm{mol} / \mathrm{L}), \mathrm{F} 9202(1 \mu \mathrm{mol} / \mathrm{L}), \mathrm{F} 9204(1 \mu \mathrm{mol} / \mathrm{L})$, and DHE $(1 \mu \mathrm{mol} / \mathrm{L})$ for $24 \mathrm{~h}$ at $37^{\circ} \mathrm{C}$. The intracellular cAMP levels were determined as described in the Materials and methods in the presence of $10 \mu \mathrm{mol} / \mathrm{L}$ naloxone. Forskolin-stimulated CAMP accumulation in the absence of opioid agonist was defined as $100 \%$, and the percentage of intracellular cAMP level was calculated from the forskolin control value. Data are presented as means \pm SEM of at least three independent experiments performed in triplicate. ${ }^{\circ} P<0.001$ vs DHE-treated group. (one-way ANOVA, Tukey post tests).

The relationship between the RAVE value of F9202, F9204, DHE as well as morphine and their liability to cause dependence

Several lines of evidence suggest that there is a relationship between the RAVE value of an agonist and its propensity to cause tolerance and dependence ${ }^{[14,17]}$. Data mentioned above showed that F9202, F9204, DHE, and morphine exhibited different abilities to stimulate the binding of $\left[{ }^{35} \mathrm{~S}\right] \mathrm{GTP} \gamma \mathrm{S}$ to receptors, suppress adenylyl cyclase activity and induce MORs internalization. Additionally, there is also evidence showing that these compounds display great differences in their roles in developing physical and psychological dependence ${ }^{[28-33]}$ and in producing CAMP overshoot ${ }^{[34]}$. To further test the relation- 
ship between the RAVE value of an agonist and its propensity to cause dependence, the RAVE values of the four agonists were calculated based on the data obtained from the present in vitro study and previous in vivo studies ${ }^{[35,36]}$. We then correlated the RAVE values to the physical and psychological dependence observed by our and other's previous studies and to the CAMP overshoot observed in the present study. According to the RAVE model ${ }^{[14]}$, the values of DHE required to stimulate $\left[{ }^{35} \mathrm{~S}\right] \mathrm{GTP} \gamma \mathrm{S}$ binding, inhibit AC, attenuate antinociception and induce endocytosis were defined as 1 . Thus, the RAVE of DHE was 1 (Table 1). As shown in Table 1, morphine had a much greater RAVE value than that of the other three compounds. The rank order of the RAVE values was morphine $>$ F9202>F9204>DHE. Accordingly, morphine displayed a greater liability to induce psychological dependence relative to the other three compounds ${ }^{[29]}$. However, based on the results from the present in vitro cAMP overshoot assay and our previous in vivo physical dependence comparison ${ }^{[28]}$, F9202 displayed an extraordinarily strong ability to induce physical and cAMP overshoot. Altogether, these observations indicate that agonists with lower RAVE values such as DHE, F9204, and F9202 are less likely to induce psychological dependence than those with higher RAVE values such as morphine. However, similar correlations between RAVE values and their liability to develop physical dependence and to induce cAMP overshoot have not been observed.

\section{Discussion}

Recently, Whistler and her colleagues have addressed the relationship between the ability of agonists to induce MOR endocytosis and their liability to develop opioid dependence ${ }^{[14]}$. They showed that opioid agonists with a strong ability to promote endocytosis may have a reduced propensity to promote opioid dependence ${ }^{[12,14]}$. Based on their findings, they suggest that the value of RAVE (relative activity versus endocytosis) of an opioid agonist might predict its liability to develop dependence. For example, they have shown that methadone, which is thought to have less dependence potential than morphine, has a lower RAVE than morphine ${ }^{[14]}$. They also demonstrated that facilitation of MOR endocytosis/resensitization is an effective strategy to reduce opioid withdrawal in cultured cells ${ }^{[24]}$ as well as in animal models ${ }^{[37,38]}$. In contrast, the in vitro findings of Koch et al implied that opioids with high endocytotic efficacy tend to induce an enhanced opioid dependence ${ }^{[39]}$. Therefore, the relationship between RAVE value and opioid dependence liability is still controversial. Herein, we chose four representative opioids to further explore this relationship because our and other's previous studies showed that F9202, F9204, DHE, and morphine all have a potent analgesic efficacy but exhibit quite different dependence profiles ${ }^{[28-33,35,36,40]}$.

F9202 and F9204 are two of the eight stereoisomers of ohmefentanyl. These two isomers have similarly potent analgesic activity and a high selectivity for MOR but display significant differences in dependence potential ${ }^{[28,35]}$. F9202 has a much stronger potential to induce physical dependence than F9204. Accordingly, DHE has been reported to possess an extraordi- narily potent antinociceptive action (1000-12 000 times more effective than morphine) and a highly selective MOR affinity, but has also been shown to be less likely to induce physical and psychological dependence than morphine ${ }^{[30-33,36,40,41]}$.

The results of the present study demonstrated that DHE had the lowest RAVE value, while morphine had the highest RAVE value. Likewise, F9204 and F9202 had lower RAVE values relative to morphine but displayed less psychological dependence than morphine ${ }^{[29]}$. These findings are consistent with the RAVE hypothesis that agonists with lower RAVE values are less likely to induce psychological dependence. It has also been shown consistently that agonists with stronger endocytotic potency produce less sensitization to locomotor stimulation, which is thought to be a correlate of certain aspects of drug addiction (psychological dependence) ${ }^{[42]}$. However, although our observations are consistent with the RAVE theory of psychological dependence, similar correlations of RAVE values to their liability to develop physical dependence or induce CAMP overshoot have not been found in the present study. For example, the RAVE value of F9202 is far less than that of morphine, whereas the physical dependence potency is much stronger than ${ }^{[28]}$ and the cellular dependence potency is the same as that of morphine (Figure 4). This discrepancy between psychological and physical/cellular dependence potency may be due to the different mechanisms of cellular signaling pathways, which contribute to the development of psychological and physical/cellular dependence.

In conclusion, our observations suggest that the RAVE value of agonists may be predictive of the liability to develop psychological dependence but not of the liability to develop physical dependence or cAMP overshoot. Taken together, future studies are still needed to address the RAVE hypothesis by investigating a large number of opioids ${ }^{[43,44]}$ (which differ in RAVE values and dependence) in a more complex neuronal system.

\section{Acknowledgements}

We thank Prof Jin LI for generously providing the DHE.

\section{Author contribution}

Yu-hua WANG designed and performed the research and wrote the paper. Jian-feng SUN assisted in the research. Yimin TAO and Xue-jun XU helped with data analysis. Zhiqiang CHI provided consultation. Jing-gen LIU designed the research and revised the paper.

\section{References}

1 Matthes HW, Maldonado R, Simonin F, Valverde O, Slowe S, Kitchen I, et al. Loss of morphine-induced analgesia, reward effect and withdrawal symptoms in mice lacking the mu-opioid-receptor gene. Nature 1996; 383: 819-23.

2 Kieffer BL. Opioids: first lessons from knockout mice. Trends Pharmacol Sci 1999; 20: 19-26.

3 Berrendero F, Kieffer BL, Maldonado R. Attenuation of nicotineinduced antinociception, rewarding effects, and dependence in muopioid receptor knock-out mice. J Neurosci 2002; 22: 10935-40.

4 von Zastrow M, Svingos A, Haberstock-Debic H, Evans C. Regulated 
endocytosis of opioid receptors: cellular mechanisms and proposed roles in physiological adaptation to opiate drugs. Curr Opin Neurobiol 2003; 13: 348-53.

5 Ferguson SS. Evolving concepts in G protein-coupled receptor endocytosis: the role in receptor desensitization and signaling. Pharmacol Rev 2001; 53: 1-24.

6 Liu JG, Anand KJ. Protein kinases modulate the cellular adaptations associated with opioid tolerance and dependence. Brain Res Brain Res Rev 2001; 38: 1-19.

7 He L, Fong J, von Zastrow M, Whistler JL. Regulation of opioid receptor trafficking and morphine tolerance by receptor oligomerization. Cell 2002; 108: 271-82.

8 Alvarez V, Arttamangkul S, Williams JT. A RAVE about opioid withdrawal. Neuron 2001; 32: 761-3.

9 Koch T, Hollt V. Role of receptor internalization in opioid tolerance and dependence. Pharmacol Ther 2008; 117: 199-206.

10 Keith DE, Murray SR, Zaki PA, Chu PC, Lissin DV, Kang L, et al. Morphine activates opioid receptors without causing their rapid internalization. J Biol Chem 1996; 271: 19021-4.

11 Patel MB, Patel CN, Rajashekara V, Yoburn BC. Opioid agonists differentially regulate mu-opioid receptors and trafficking proteins in vivo. Mol Pharmacol 2002; 62: 1464-70.

12 Martini L, Whistler JL. The role of mu opioid receptor desensitization and endocytosis in morphine tolerance and dependence. Curr Opin Neurobiol 2007; 17: 556-64.

13 Nestler EJ. Under siege: The brain on opiates. Neuron 1996; 16: 897-900.

14 Whistler JL, Chuang HH, Chu P, Jan LY, von Zastrow M. Functional dissociation of mu opioid receptor signaling and endocytosis: implications for the biology of opiate tolerance and addiction. Neuron 1999; 23: 737-46.

15 Sternini C, Spann M, Anton B, Keith DE Jr, Bunnett NW, von Zastrow M, et al. Agonist-selective endocytosis of mu opioid receptor by neurons in vivo. Proc Natl Acad Sci USA 1996; 93: 9241-6.

16 Koch T, Schulz S, Schroder H, Wolf R, Raulf E, Hollt V. Carboxylterminal splicing of the rat mu opioid receptor modulates agonistmediated internalization and receptor resensitization. J Biol Chem 1998; 273: 13652-7.

17 Roth BL, Willins DL. What's all the RAVE about receptor internalization? Neuron 1999; 23: 629-31.

18 Liu JG, Prather PL. Chronic agonist treatment converts antagonists into inverse agonists at delta-opioid receptors. J Pharmacol Exp Ther 2002; 302: 1070-9.

19 Hong MH, Xu C, Wang YJ, Ji JL, Tao YM, Xu XJ, et al. Role of Src in ligand-specific regulation of delta-opioid receptor desensitization and internalization. J Neurochem 2009; 108: 102-14.

20 Hiebel AC, Lee YS, Bilsky E, Giuvelis D, Deschamps JR, Parrish DA, et al. Probes for narcotic receptor mediated phenomena. 34. Synthesis and structure-activity relationships of a potent mu-agonist delta-antagonist and an exceedingly potent antinociceptive in the enantiomeric C9-substituted 5-(3-hydroxyphenyl)- $\mathrm{N}$-phenylethylmorphan series. J Med Chem 2007; 50: 3765-76.

21 Alt A, McFadyen IJ, Fan CD, Woods JH, Traynor JR. Stimulation of guanosine-5'-o-(3-[35S]thio)triphosphate binding in digitonin-permeabilized $\mathrm{C} 6$ rat glioma cells: evidence for an organized association of mu-opioid receptors and G protein. J Pharmacol Exp Ther 2001; 298: 116-21.

22 Sharma SK, Klee WA, Nirenberg M. Opiate-dependent modulation of adenylate cyclase. Proc Natl Acad Sci USA 1977; 74: 3365-9.

23 Keith DE, Anton B, Murray SR, Zaki PA, Chu PC, Lissin DV, et al. muopioid receptor internalization: opiate drugs have differential effects on a conserved endocytic mechanism in vitro and in the mammalian brain. Mol Pharmacol 1998; 53: 377-84.

24 Finn AK, Whistler JL. Endocytosis of the mu opioid receptor reduces tolerance and a cellular hallmark of opiate withdrawal. Neuron 2001; 32: 829-39.

25 Liu JG, Gong ZH, Qin BY. Effects of opioid receptor agonists on cAMP second messenger system. Zhongguo Yao Li Xue Bao 1999; 20: 452-6.

26 Collier HO, Francis DL. Morphine abstinence is associated with increased brain cyclic AMP. Nature 1975; 255: 159-62.

27 Nestler EJ, Aghajanian GK. Molecular and cellular basis of addiction. Science 1997; 278: 58-63.

28 Guo GW, He Y, Jin WQ, Zou Y, Zhu YC, Chi ZQ. Comparison of physical dependence of ohmefentanyl stereoisomers in mice. Life Sci 2000; 67: 113-20.

29 Guo GW, Liu ZH, Jin WQ, Zhang HP, Chen XJ, Zhu YC, et al. Quantitative comparison of ohmefentanyl isomers induced conditioning place preference in mice. Life Sci 2001; 68: 2383-90.

30 Tokuyama S, Takahashi M, Kaneto $\mathrm{H}$. Antinociceptive effect of dihydroetorphine and its tolerance/dependence liability in mice. Biol Pharm Bull 1993; 16: 774-7.

31 Tokuyama S, Nakamura F, Nakao K, Takahashi M, Kaneto H. A potent mu-opioid receptor agonist, dihydroetorphine, fails to produce the conditioned place preference in mice. Jpn J Pharmacol 1996; 71: 357-60.

32 Ohmori S, Morimoto Y. Dihydroetorphine: a potent analgesic: pharmacology, toxicology, pharmacokinetics, and clinical effects. CNS Drug Rev 2002; 8: 391-404.

33 Huang M, Wang DX, Qin BY. Dihydroetorphine, a potent opioid with low dependent potential. Regul Peptides 1994; 53: S81-S82.

34 Liu ZH, He Y, Jin WQ, Chen XJ, Shen QX, Chi ZQ. Effect of chronic treatment of ohmefentanyl stereoisomers on cyclic AMP formation in Sf9 insect cells expressing human mu-opioid receptors. Life Sci 2004; 74: 3001-8.

35 Jin WQ, Wang ZX, Chen J, Chen XJ, Chi ZQ. Analgesic activity and selectivity for opioid receptors of enantiomers of ohmefentanyl. Zhongguo Yao Li Xue Bao 1996; 17: 421-4.

36 Huang M, Qin BY. Analgesic and other CNS depressive effects of dihydroetorphine. Zhongguo Yao Li Xue Bao 1982; 3: 9-13.

$37 \mathrm{He} \mathrm{L}$, Whistler JL. An opiate cocktail that reduces morphine tolerance and dependence. Curr Biol 2005; 15: 1028-33.

38 Kim JA, Bartlett S, He L, Nielsen CK, Chang AM, Kharazia V, et al. Morphine-induced receptor endocytosis in a novel knockin mouse reduces tolerance and dependence. Curr Biol 2008; 18: 129-35.

39 Koch T, Widera A, Bartzsch K, Schulz S, Brandenburg LO, Wundrack $\mathrm{N}$, et al. Receptor endocytosis counteracts the development of opioid tolerance. Mol Pharmacol 2005; 67: 280-7.

$40 \mathrm{Cao} \mathrm{GH}$, Chen H, Cai ZJ. Drug dependence on dihydroetorphine. Zhongguo Lin Chuang Yao Li Xue Za Zhi 1990; 6: 54-59.

41 Wang DX, Lu XQ, Qin BY. Dihydroetorphine is a mu-receptor-selective ligand. J Pharm Pharmacol 1995; 47: 669-73.

42 Grecksch G, Bartzsch K, Widera A, Becker A, Hollt V, Koch T. Development of tolerance and sensitization to different opioid agonists in rats. Psychopharmacology (Berl) 2006; 186: 177-84.

43 Zhang Z, Shao YC, Li SJ, Qi JL, Zhang MJ, Hao W, et al. Medication of I-tetrahydropalmatine significantly ameliorates opiate craving and increases the abstinence rate in heroin users: a pilot study. Acta Pharmacol Sin 2008; 29: 781-8.

44 Zhang JL, Wang $\mathrm{H}$, Chen $\mathrm{C}$, Pi HF, Raun HL, Zhang P, et al. Addictive evaluation of cholic acid-verticinone ester, a potential cough thera peutic agent with agonist action of opioid receptor. Acta Pharmacol $\operatorname{Sin} 2009$; 30: 559-66. 